\title{
Nonradioactive Air Emissions Notice of Construction for Removal of 340A Building Tank Solids
}




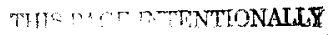
JiLNK

1 


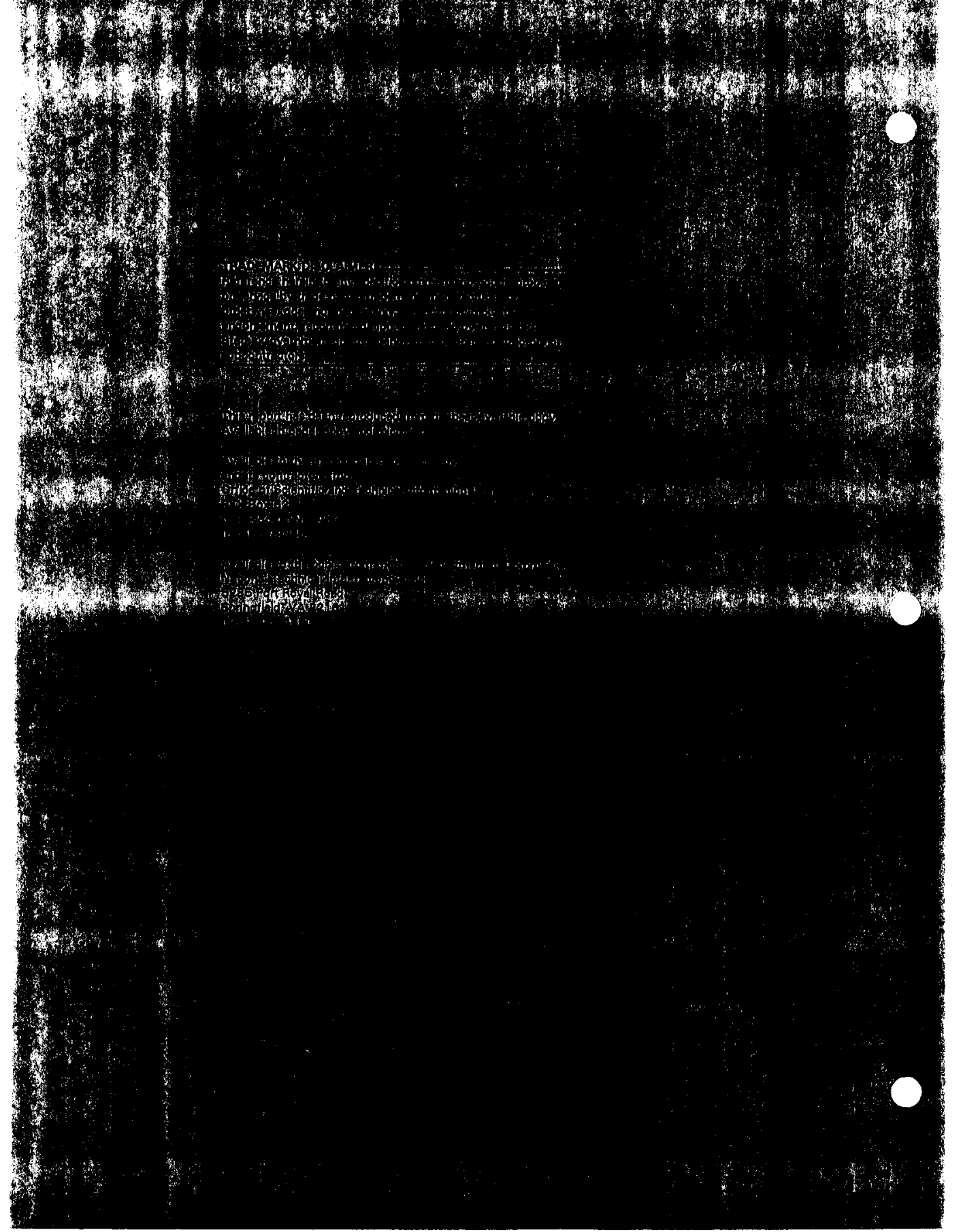




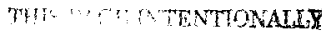

$\therefore \quad$ OLNKK

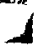




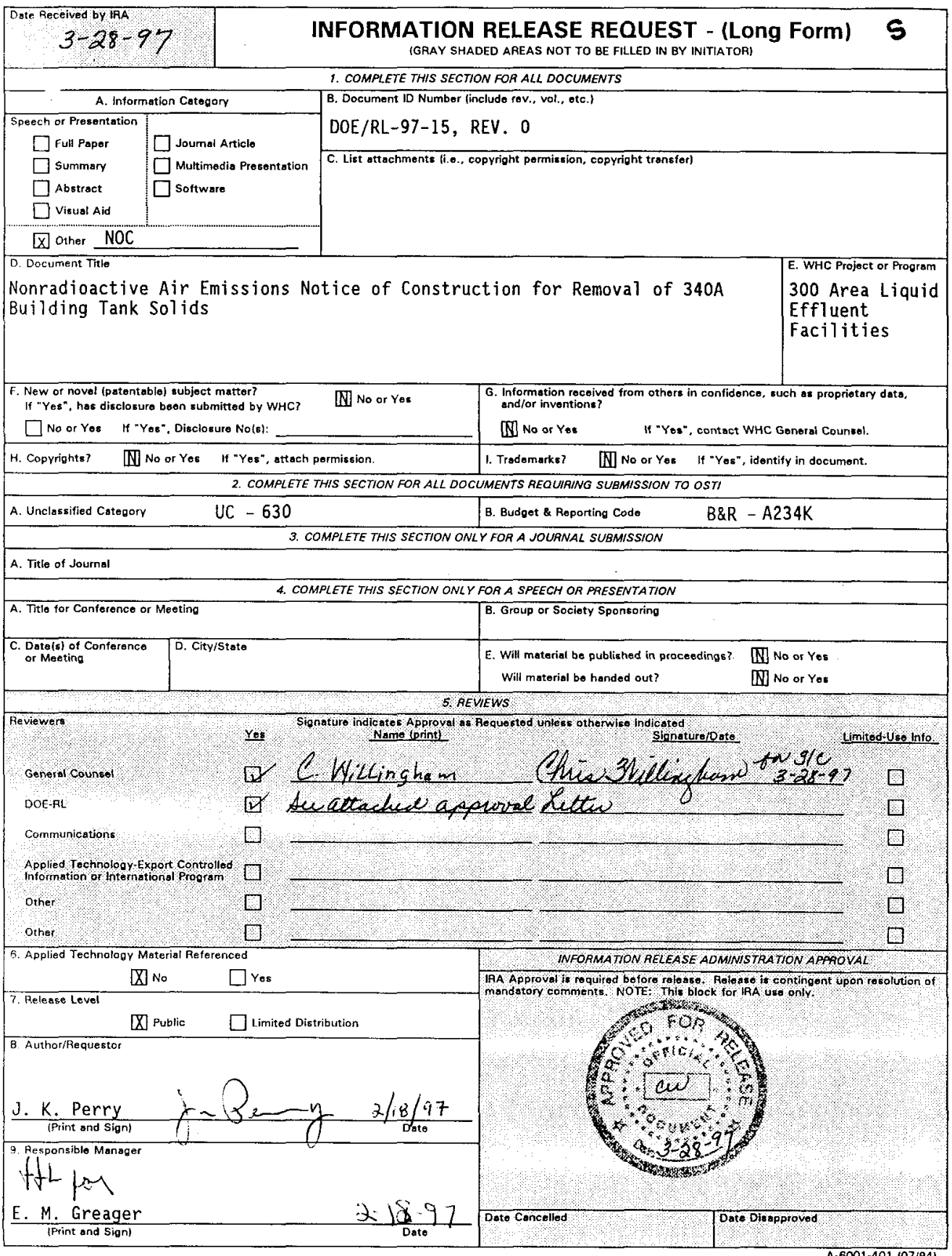


DOE/RL-97-15, REV. 0 Document ID Numbar

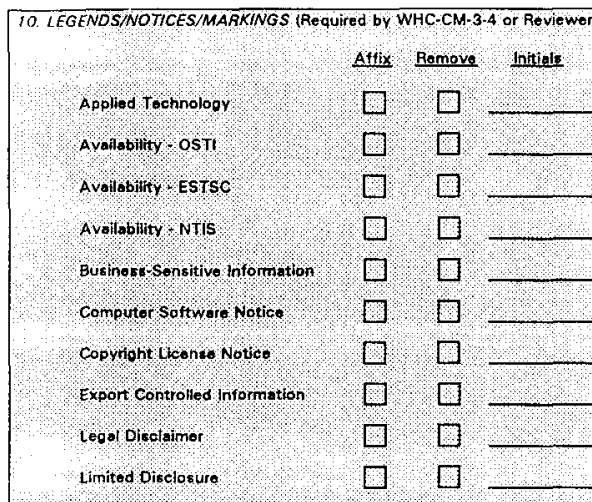

11 MANOATORY COMMENTS S List only hendatory tomments hate. All othe comment thall to mode on the document ond retumed to the suthor.

offorial Uce only

Patort stotus

Prodocisional loformotion

Proorammatic Notico

Poprotang intomation

Purpo ofo ond Uso

Thentutoistortation

Trademark Ofeclaimer

othon
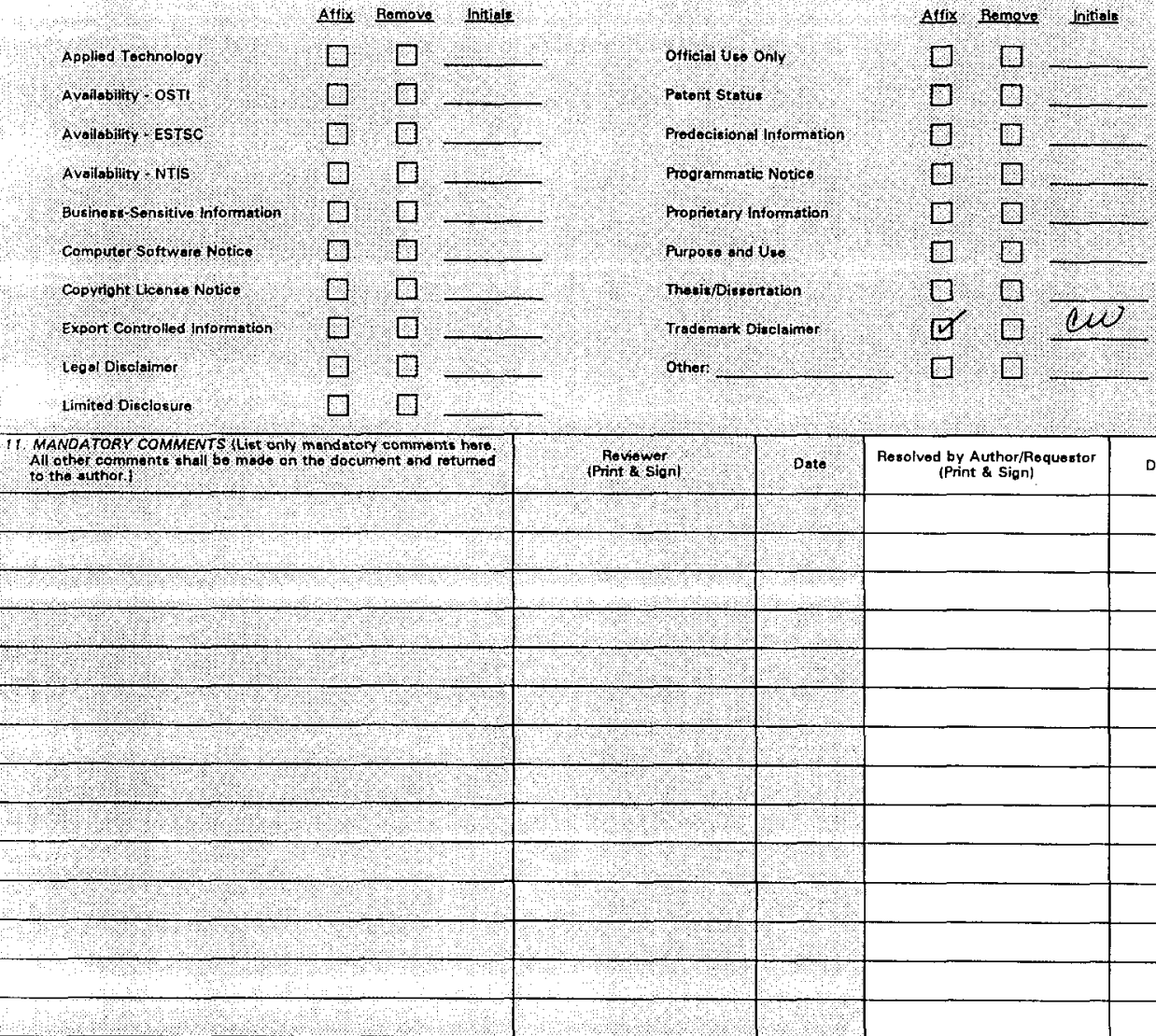

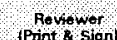

IPrint 2 ston

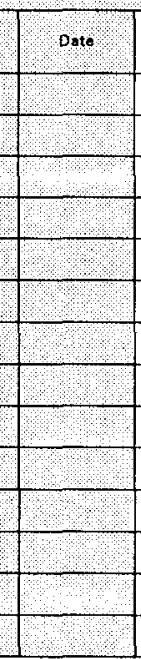

Resolved by Author/Requestor (Print \& Sign) 


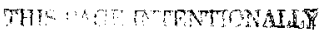

[i. ANE J 


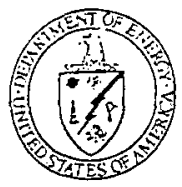

\author{
Department of Energy \\ Richlend Operations Office \\ P.O. Box 550 \\ Richland, Washington 99352
}

\title{
MAR $26199 \%$
}

97-EAP-312

Mr. Marcel szyzskowski, P.E.

Regulatory and Technical

Support Section

Nuclear Waste Program

State of Kashington

Department of Ecology

P. 0. Box 47600

0)ympia, Washington $98504-7600$

Dear Mr. Szyszkowski:

NONRADIOACTIVE AIR EMISSIONS NOTICE OF CONSTRUCTION (NOC) FOR REMOVAL OF $340 \mathrm{~A}$ BUILOING TAIKK SOLIOS

This letter transmits a NOC to the State of Washington Department of Ecology (Ecology), pursuant to hashington Administrative Code 173-460. Enclosed, please find a NOC requesting Ecology's approval for construction/modification for removal of $340 \mathrm{~A}$ Building tank solids.

Should you have any questions, please contact me or Hector M. Rodriguez, of my staff, at (509) 376-6421.

EAP : HILR

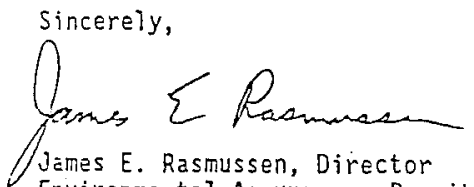

Environmental Assurance, Permits,

Enclosure

cc W/encl:

W. Adair, FDH

- R. Jim, YIN

$\therefore$ D. Powaukée, NPT

L. Roberts, RFSH

J. Wilkinson, CTUIR

cc W/o encl:

J. Luke, RFSH

c. Mattsson, FDH

L. Roberts, RFSH 


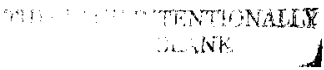




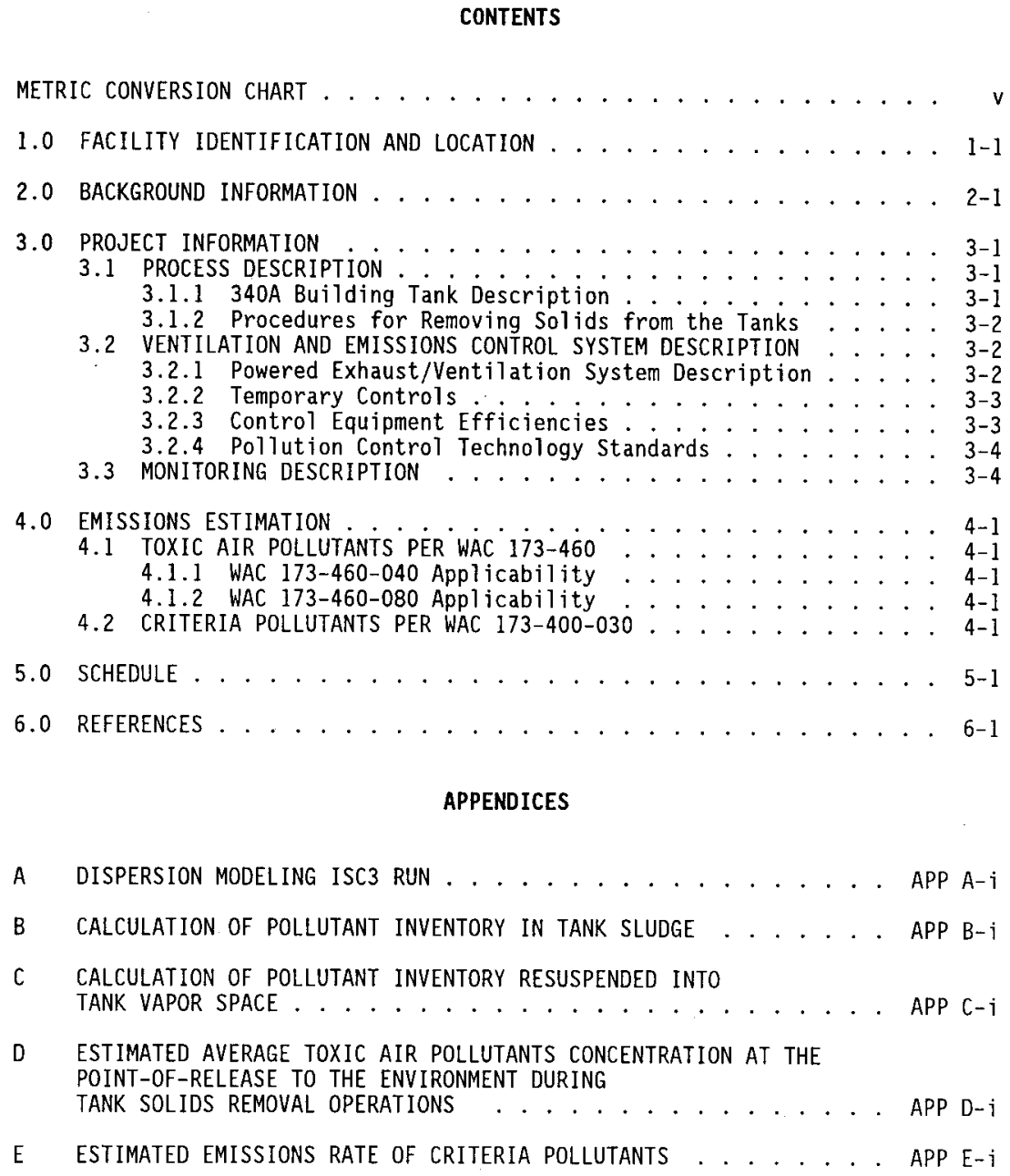


1. Hanford Site .................. 1-2

2. Location of the $340 \mathrm{~A}$ Facility within the 300 Area $\ldots 1-3$

3. Ventilation and Emissions Control System Diagram .......

7

8

\section{TABLES}

11

1. Toxic Air Pollutants Emissions ... . . . . . . . . . 4-2

2. Criteria Pollutant Emissions ............... 4-3 


\begin{tabular}{|c|c|c|c|c|c|}
\hline $\begin{array}{r}\text { The follo } \\
\text { aid in convers } \\
\text { Int }\end{array}$ & $\begin{array}{l}\text { wing convers } \\
\text { ion. } \\
\text { o metric uni }\end{array}$ & $\begin{array}{l}\text { ion chart is } \\
\text { ts }\end{array}$ & $\begin{array}{r}\text { ovided to th } \\
\text { Out }\end{array}$ & reader as & tool to \\
\hline If you know & $\begin{array}{l}\text { Multiply } \\
\text { by }\end{array}$ & To get & If you know & $\begin{array}{c}\text { Multiply } \\
\text { by }\end{array}$ & To get \\
\hline \multicolumn{3}{|c|}{ Length } & \multicolumn{3}{|c|}{ Length } \\
\hline inches & 25.40 & millimeters & millimeters & 0.0393 & inches \\
\hline inches & 2.54 & centimeters & centimeters & 0.393 & inches \\
\hline feet & 0.3048 & meters & meters & 3.2808 & feet \\
\hline yards & 0.914 & meters & meters & 1.09 & yards \\
\hline mjles & 1.609 & kilometers & kilometers & 0.62 & miles \\
\hline \multicolumn{3}{|c|}{ Area } & \multicolumn{3}{|c|}{ Area } \\
\hline $\begin{array}{l}\text { square } \\
\text { inches }\end{array}$ & 6.4516 & $\begin{array}{l}\text { square } \\
\text { centimeters }\end{array}$ & $\begin{array}{l}\text { square } \\
\text { centimeters }\end{array}$ & 0.155 & $\begin{array}{l}\text { square } \\
\text { inches }\end{array}$ \\
\hline square feet & 0.092 & $\begin{array}{l}\text { square } \\
\text { meters }\end{array}$ & $\begin{array}{l}\text { square } \\
\text { meters }\end{array}$ & 10.7639 & $\begin{array}{l}\text { square } \\
\text { feet }\end{array}$ \\
\hline $\begin{array}{l}\text { square } \\
\text { yards }\end{array}$ & 0.836 & $\begin{array}{l}\text { square } \\
\text { meters }\end{array}$ & $\begin{array}{l}\text { square } \\
\text { meters }\end{array}$ & 1.20 & $\begin{array}{l}\text { square } \\
\text { yards }\end{array}$ \\
\hline $\begin{array}{l}\text { square } \\
\text { mijes }\end{array}$ & 2.59 & $\begin{array}{l}\text { square } \\
\text { kilometers }\end{array}$ & $\begin{array}{l}\text { square } \\
\text { kilometers }\end{array}$ & 0.39 & $\begin{array}{l}\text { square } \\
\text { miles }\end{array}$ \\
\hline acres & 0.404 & hectares & hectares & 2.471 & acres \\
\hline \multicolumn{3}{|c|}{ Mass (weight) } & \multicolumn{3}{|c|}{ Mass (weight) } \\
\hline ounces & 28.35 & grams & grams & 0.0352 & ounces \\
\hline pounds & 0.453 & kilograms & kilograms & 2.2046 & pounds \\
\hline short ton & 0.907 & metric ton & metric ton & 1.10 & short ton \\
\hline \multicolumn{3}{|c|}{ Volume } & \multicolumn{3}{|c|}{ Volume } \\
\hline $\begin{array}{l}\text { fluid } \\
\text { ounces }\end{array}$ & 29.57 & milliliters & milliliters & 0.03 & $\begin{array}{l}\text { fluid } \\
\text { ounces }\end{array}$ \\
\hline quarts & 0.95 & liters & Titers & 1.057 & quarts \\
\hline gallons & 3.79 & liters & liters & 0.26 & gallons \\
\hline cubic feet & 0.03 & $\begin{array}{l}\text { cubic } \\
\text { meters }\end{array}$ & $\begin{array}{l}\text { cubic } \\
\text { meters }\end{array}$ & 35.3147 & cubic feet \\
\hline cubic yards & 0.76456 & $\begin{array}{l}\text { cubic } \\
\text { meters }\end{array}$ & $\begin{array}{l}\text { cubic } \\
\text { meters }\end{array}$ & 1.308 & $\begin{array}{l}\text { cubic } \\
\text { yards }\end{array}$ \\
\hline \multicolumn{3}{|c|}{ Temperature } & \multicolumn{3}{|c|}{ Temperature } \\
\hline Fahrenheit & $\begin{array}{l}\text { subtract } \\
32 \text { then } \\
\text { multiply } \\
\text { by } 5 / 9 \text { ths }\end{array}$ & Celsius & Celsius & $\begin{array}{l}\text { multiply } \\
\text { by } \\
9 / 5 \text { ths, } \\
\text { then add } \\
32\end{array}$ & Fahrenheit \\
\hline \multicolumn{3}{|c|}{ Force } & \multicolumn{3}{|c|}{ Force } \\
\hline $\begin{array}{l}\text { pounds per } \\
\text { square inch }\end{array}$ & 6.895 & kilopascals & kilopascals & $\begin{array}{l}1.4504 \times \\
10^{-4}\end{array}$ & $\begin{array}{l}\text { pounds per } \\
\text { square } \\
\text { inch }\end{array}$ \\
\hline
\end{tabular}

Source: Engineering Unit Conversions, M. R. Lindeburg, PE., Second Ed., 41 1990, Professional Publications, Inc., Belmont, California. 
DOE/RL-97-15, Rev. 0 02/97.

This page intentionally left blank. 


\section{NONRADIOACTIVE AIR EMISSIONS NOTICE OF CONSTRUCTION FOR REMOVAL OF 340A BUILDING TANK SOLIDS}

\subsection{FACILITY IDENTIFICATION AND LOCATION}

The $340 \mathrm{~A}$ Building tanks are located within the 340 Facility Complex in the 300 Area of the Hanford Site. Figure l shows the location of the 300 Area within the Hanford Site. Figure 2 shows the location of the 340 Facility Complex within the 300 Area. The Washington State Plane Coordinates for the 340A Facility are: N54475 E15475.

Address:

U.S. Department of Energy, Richland Operations Office Hanford Site 300 Area, 340 Facility

Richland, Washington 99352

The responsible manager's name and address are as follows:

Mr. T. K. Teynor Waste Programs Division U.S. Department of Energy, Richland Operations Office P.0. Box 550, Mail Stop S7-55 Richland, Washington 99352 (509) 372-1926. 


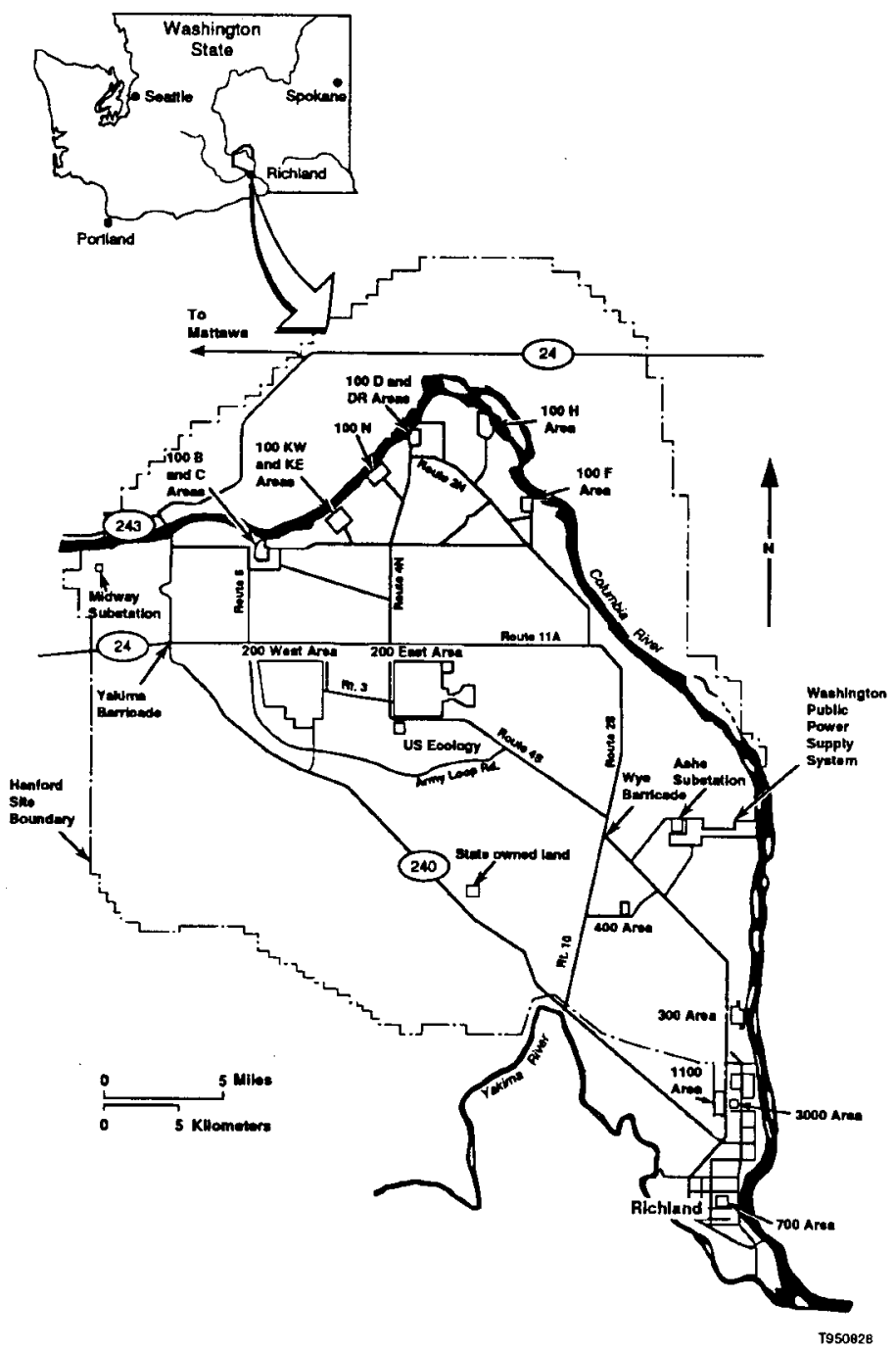

Figure 1. Hanford Site. 


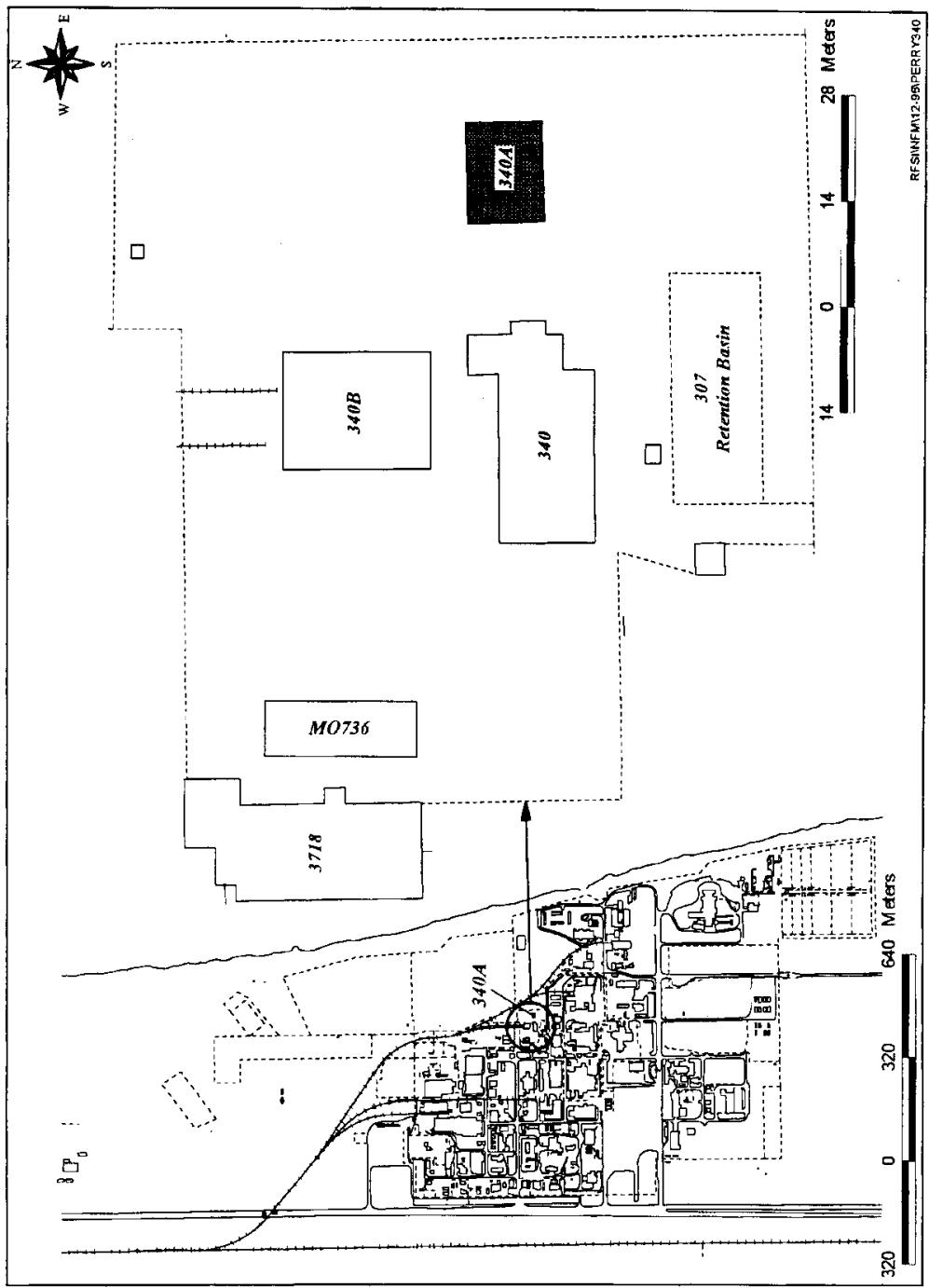

Figure 2. Location of the $340 \mathrm{~A}$ Facility within the 300 Area. 


\section{D0E/RL-97-15, Rev. 0}

$02 / 97$

This page intentionally left blank. 


\subsection{BACKGROUND INFORMATION}

The 340 Complex is a less-than-90-day storage unit for mixed waste generated on the Hanford Site. The 340 Complex receives liquid waste from various buildings in the 300 Area via underground transfer lines, or by containers from generators supporting Hanford Site programs.

The tanks used for waste storage at the 340 Complex include two 57 kiloliter tanks within the 340 Underground Storage Vault and six 30 kiloliter tanks within the $340 \mathrm{~A}$ Building. The two underground vault tanks provide primary waste storage while the six tanks in the $340 \mathrm{~A}$ Building provide reserve storage capacity.

The $340 \mathrm{~A}$ Building tanks are not equipped with agitation devices and/or equipment. Consequently, past usage of the tanks has resulted in the formation, deposition, and settling of waste water solids.

The deposited tank solids contain radioactive material that represent a source of radiation exposure to workers. For as low as reasonably achievable (ALARA) purposes, the solids must be removed periodically from the tanks. The most recent tank solids removal effort occurred in the early $1980 \mathrm{~s}$.

The removal of solids from the $340 \mathrm{~A}$ Building tanks constitutes a modification, in accordance with WAC 173-460-020(14), and, in accordance with WAC 173-460-040, the proposed activities are subject to New Source Review. In accordance with WAC 173-460 and WAC 173-400, this document serves as a Notice of Construction (NOC) for periodically removing solids from the $340 \mathrm{~A}$ Building tanks.

It should be noted that submittal of this document is intended to conditionally satisfy WAC 173-460 and WAC 173-400 NOC requirements for future tank solids removal campaigns. Future solids removal campaigns will be performed on an as-needed basis to support ALARA practices and/or principles, and there might be several years between campaigns. It is understood that future $340 \mathrm{~A}$ Building tank solids removal campaigns will be considered to have satisfied WAC 173-460 and WAC 173-400 NOC requirements, if the following conditions are met (note: a campaign consists of the removal of all sludge in the subject tanks).

- Potential pollutant emissions from each campaign will not exceed the levels stated in this document.

- No more than one tank solids removal campaign will be performed during any given annual period.

- Potential toxic air pollutant (TAP) and Criteria Pollutant emissions shall be limited to those identified in this NOC.

- The pollution control measures stated in this document are implemented. 
DOE/RL-97-15, Rev. 0

$02 / 97$

1
2
3
4
5

This page intentionally left blank. 


\subsection{PROJECT INFORMATION}

Provided in this section are descriptions of applicable processes, ventilation and emissions controls, and monitoring.

\subsection{PROCESS DESCRIPTION}

The following sections provide descriptions of the $340 \mathrm{~A}$ Building tanks and the proposed procedures for removing solids from the tanks.

\subsubsection{A Building Tank Description}

The $340 \mathrm{~A}$ Building tanks are described as follows.

- The tanks are housed in the 340A Building.

- The tanks consist of six aboveground stainless steel tanks.

- The approximate volume of each tank is 30 kiloliters.

- The dimensions for each tank are approximately 3 meters in diameter and 4.2 meters high.

- The top of each tank is provided with an access port (access 1id) which is, approximately 0.46 meter in diameter.

- Each tank is provided with a fill/drain port located on the tank side wal1, approximately 0.15 meters above the bottom surface of the tank.

- The tank fill/drain ports, drain via hard piping, to the 340 Vault tanks.

- The tanks are interconnected via hard pipes.

- The tanks are maintained at negative pressure relative to the atmosphere via the 340 Facility $K 1$ powered exhaust/ventilation system (the differential pressure is $>6$ inches water gauge).

- The combined volume of sludge in the six tanks is approximately 1,670 liters.

- The tank sludge consist of water, radioactive particulates, metals, and hard water mineral salts. 


\subsubsection{Procedures for Removing Solids from the Tanks}

The following methods will be employed to remove solids from the $340 \mathrm{~A}$ Building tanks.

- Temporary containment device(s) will be configured to maintain negative pressure within the tanks by restricting the amount of air that enters the tanks via the tank access ports.

- The access lid will be removed from the tanks.

- An agitating device (air sparger, liquid pressure washer, or recirculating pump) and cleaning solution to aid in the solids suspension will be inserted into the tank access ports.

- The agitating device will be activated.

- Tanks will be drained to the 340 Vault tanks via the tank fill/drain valves.

- Solids agitation activities are expected to require approximately 2 hours per tank.

- After completing solids agitation and draining activities, the agitation equipment will be removed from the tanks by retracting the equipment into plastic sleeving.

- On removing the agitation equipment from tanks, the tank access 1 ids will be replaced.

\subsection{VENTILATION AND EMISSIONS CONTROL SYSTEM DESCRIPTION}

The following sections describe:

- Powered exhaust/ventilation system serving the $340 \mathrm{~A}$ Building tanks

- Temporary controls to be implemented when accessing tanks

- Control equipment efficiencies

- Pollution control technology standards.

\subsubsection{Powered Exhaust/Ventilation System Description}

The 340 Facility $K 1$ powered exhaust/ventilation system ventilates the $340 \mathrm{~A}$ Building Tanks. Parameters associated with the operation of the Kl powered exhaust/ventilation system include the following:

- The exhaust stack inner diameter at point of release to the environment is approximately 46 centimeters. 
- Exhaust stack height is approximately 6.1 meters above ground level.

- Maximum flow rate of powered exhaust/ventilation system is approximately 68 cubic meters per minute.

- Average (actual) powered exhaust/ventilation flow rate is approximately 50.2 cubic meters per minute.

- Supply air for the 340 Facility KI powered exhaust/ventilation system is heated electrically in the winter to protect pipes from freezing.

- Powered exhaust/ventilation system pollution control equipment consists of a prefilter and two banks of high efficiency particulate filter media.

- An air flow diagram of the 340 Facility $\mathrm{Kl}$ powered exhaust/ventilation system is provided in Figure 3.

\subsubsection{Temporary Controls}

As noted in Section 3.1.2, temporary pollution controls will be implemented during the solids removal effort to prevent emissions of pollutants from the tank access port. Controls will consist of temporary barriers installed between the tank access port and the surrounding area. The barriers will be configured such that the amount of air that enters the tank via the tank access port is restricted sufficiently to maintain negative pressure within the tank. It should be noted that during solids removal activities, the tank differential negative pressures, with respect to the atmosphere, might be less negative than the routinely maintained differential pressures (as stated in Section 3.1.1, routine differential negative pressures are $>6$ inches water gauge).

Temporary pollution controls also will be implemented during the remova? of equipment from the tanks. Emissions will be controlled by using plastic sleeving to provide a barrier between the equipment and the surrounding work area and the environment. Equipment removed from the tanks will be retracted into a plastic sleeve. After the equipment has been retracted into the plastic sleeve, the sleeve will be sealed.

\subsubsection{Control Equipment Efficiencies}

Particulate emissions will be controlled with a prefilter and two banks of filters consisting of high-efficiency particulate filter media. The high-efficiency particulate filters that will be used are subjected to annual in-place tests, which require a particulate removal efficiency of 99.95 percent for particulates with a 0.3 micron median diameter.

To determine the overall particulate decontamination factor (DF) for the control system, the individual component DFs were multiplied together. A DF 


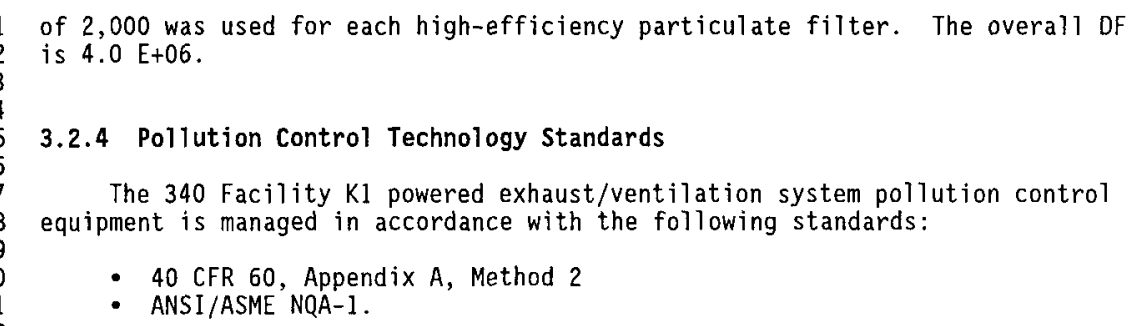

\subsubsection{Pollution Control Technology Standards}

The 340 Facility Kl powered exhaust/ventilation system pollution control equipment is managed in accordance with the following standards:

- 40 CFR 60, Appendix A, Method 2

- ANSI/ASME NQA-1.

\subsection{MONITORING DESCRIPTION}

The pollutant emissions estimation (Section 4.0) indicates that emissions are sufficiently low to protect human health and safety from potential carcinogenic and/or other toxic effects, pursuant to WAC 173-460-070 requirements. Therefore, no sampling/monitoring is proposed for nonradioactive pollutant air emissions resulting from the proposed operations. 


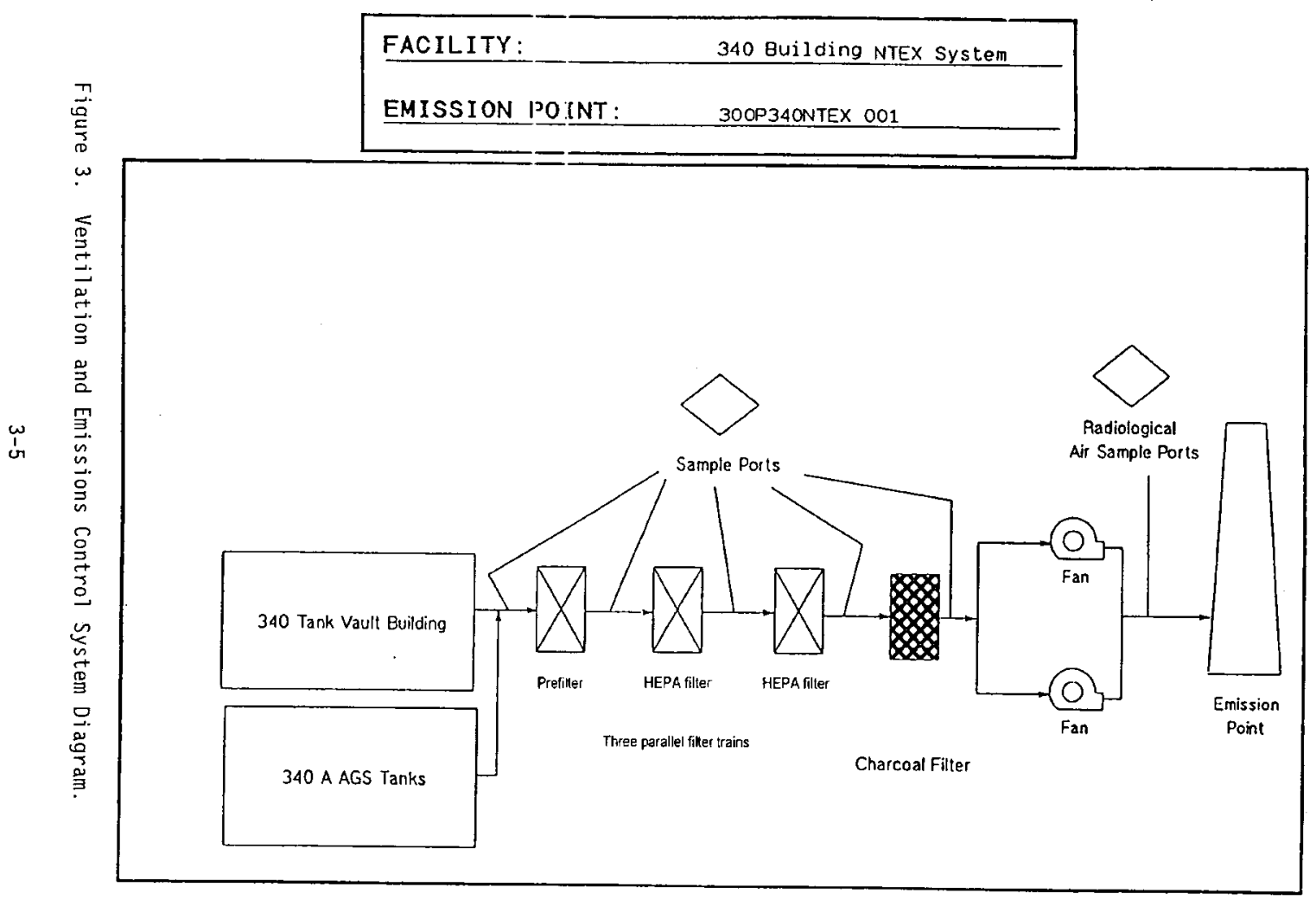


DOE/RL-97-15, Rev. 0

$02 / 97$

This page intentionally left blank. 


\subsection{EMISSIONS ESTIMATION}

This section documents estimations of TAP and Criteria Pollutant emissions resulting from the proposed activities.

\subsection{TOXIC AIR POLLUTANTS PER WAC $173-460$}

The following sections provide discussion of the applicability of WAC 173-460-040 and WAC 173-460-080 requirements for TAP emissions.

\subsection{WAC 173-460-040 Applicability}

Pursuant to WAC 173-460-040(2) requirements, increases in TAP emission rates that do not exceed levels cited in the WAC 173-460-080 Small Quantity Emission Rate (SQER) tables are not subject to New Source Review. However, the tables in WAC 173-460-080 do not provide SQERs for three of the TAPs that might be emitted during the proposed operations (Table 1). Therefore, under WAC 173-460-040 requirements, the proposed activities are subject to New Source Review.

\subsubsection{WAC 173-460-080 Applicability}

Pursuant to WAC 173-460-080 requirements, an Acceptable Source Impact Level (ASIL) analysis is required for Class A and Class B TAPs. The emissions estimation provided in this section has been prepared for the purpose of satisfying WAC 173-460-080 ASIL analys is requirements.

Table 1 provides the estimated average emission rates of TAPs at the point of release to the environment and the estimated incremental ambient values (TAP concentrations experienced by the hypothetical nearest public receptor). It should be noted that the maximum incremental impacts of Class $A$ and Class B TAPs to the hypothetical nearest public receptor are less than the associated ASILs listed in WAC 173-460-150 and WAC 173-460-160 (Table 1).

\subsection{CRITERIA POLLUTANTS PER WAC 173-400-030}

Pursuant to WAC 173-400 requirements, estimated emissions of Criteria Pollutants are provided in this section. It should be noted that one Criteria Pollutant, lead, is expected to be emitted during the solids removal activities.

The estimated emission rates of Criteria Pollutants (lead) are provided in Table 2. Data in Table 2 indicate that the maximal expected emissions of lead resulting from the proposed activities are insignificant. 


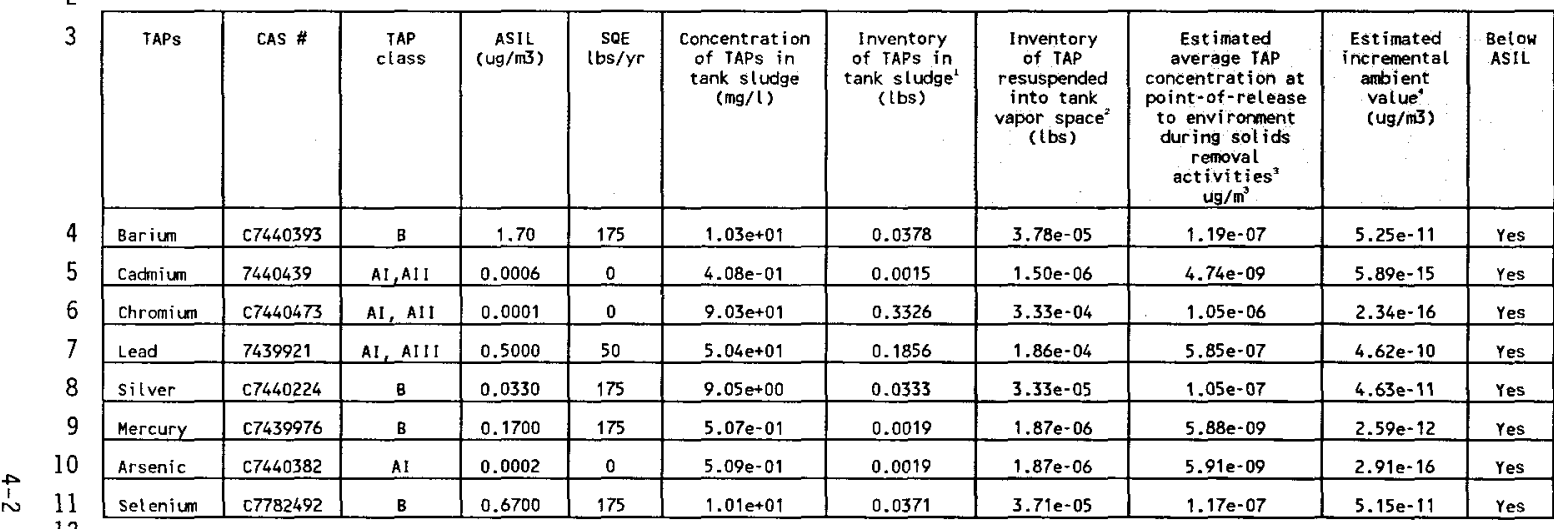
Additional information is provided in appendix B. The IAPs inventory resuspended into the tank vapor space was determined by multiplying the inventory of TAPs in the tank sludge by the 40 CFR 61, Appendix D release fraction for particulates (0.001). Additional information is provided in Appendix C. The average TAPS concentration at the point of release to the environment, during the tank solids removal activities, was calculated by dividing the TAPs inventory resuspended into the tank vapor space by the votume of gas discharged from the powered exhaust/ventilation system during the tank solids removal activities $(36,144$ cubic meters) and by multiplying by the filtration system decontamination factor (2.5 E-07). Additional information is provided in Appendix D.

The estimated incremental ambient value is the concentration experienced by the hypothetical nearest public receptor. This value was calculated using atmospheric dispersion modeling parameters provided in Appendix A. In accordance with WAC 173-460-080, the dispersion model ing factors used for lead (Pb) and Class B TAPs were derived from a 24-hour release atmospheric dispersion model, and the dispersion model ing factors used for Class AII TAPs were derived from an annual average release atmospheric dispersion model.

\footnotetext{
ASIL = acceptable source impact level.

CAS = Chemical Abstract Service.

lbs = pounds

$\mathrm{mg} / \mathrm{l}=$ milligram per liter.

SOE $=$ small quantity emissions.

$\mu g / m^{3}=$ microgram per cubic meter.
} 
2

4

5

6

7

8

9

10

11

12

13

14

15

16

17

Table 2. Criteria Pollutant Emissions.

\begin{tabular}{|c|c|c|c|}
\hline Criteria Pollutant & $\begin{array}{c}\text { Inventory of } \\
\text { pollutant in tank } \\
\text { sludge } \\
\text { (pounds) }\end{array}$ & $\begin{array}{c}\text { Quantity of } \\
\text { pollutant } \\
\text { resuspended } \\
\text { into tank vapor } \\
\text { space } \\
\text { (pounds) }\end{array}$ & $\begin{array}{c}\text { Estimated } \\
\text { emissions rate of } \\
\text { pollutant }\end{array}$ \\
(pounds per year)
\end{tabular}

1 The Criteria Pollutant inventory was calculated by multiplying the sludge concentration by the total volume of sludge (1,670 liters). Additional information is provided in Appendix B.

2 The Criteria Pollutant inventory resuspended into the tank vapor space was determined by multiplying the pollutant inventory by the 40 CFR 61 , Appendix 0 release fraction for particulates $(0.001)$. Additional information is provided in Appendix C.

3 The Criteria Pollutant emissions rate was calculated by multiplying the pollutant inventory resuspended into the tank vapor space by the filtration system decontamination factor (2.5 E-07). Note: As stated in Section 2.0, the pollutant inventory resuspended into the tank vapor space is an annual value. Additional information is provided in Appendix E. 
DOE/RL-97-15, Rev, 0

$02 / 97$

1
2
3
4
5

This page intentionally left blank. 


\subsection{SCHEDULE}

In the coming years (through calendar year 2001 and possibly beyond), the 340 Complex will continue to serve as a less-than-90-day tank storage unit for mixed waste generated on the Hanford Site. Furthermore, the 340A Building tanks will continue to provide reserve waste storage capacity.

To support future 340 Complex operations, $340 \mathrm{~A}$ Building tank solids removal activities will continue to be performed periodically. Future solids removal campaigns will be performed on an as-needed basis to support ALARA practices/principles, and there might be several years between campaigns.

The schedule for performing future solids removal activities is not provided. However, each tank solids removal campaign is expected to require approximately 6 months to complete. 
DOE/RL-97-15, Rev. 0

02/97

1
2
3
4
5

This page intentionally left blank. 


\subsection{REFERENCES}

EPA, 1996, ISC3, Industrial Source Complex Dispersion Model, screening procedures for estimating the air quality impact of stationary sources, EPA-454/B-95-003a, updated periodically, U.S. Environmental Protection Agency, Research Triangle Park, North Carolina. 
DOE/RL-97-15, Rev. 0

02/97

This page intentionally left blank.

970210.1053

$6-2$ 
DOE/RL-97-15, Rev. 0

$02 / 97$

1
2
3
4

APPENDIX A

DISPERSION MODELING ISC3 RUN 
This page intentionally left blank. 
DOE/RL-97-15, Rev. 0

$02 / 97$

$\frac{1}{2}$

DISPERSION MODELING SUMMARY 


\section{Subject: Unit Concentration Factors from ISC3}

The ISC3 program (EPA-454/B-95-003a, "User's Guide for the Industrial Source Complex (ISC3) Dispersion Models", September 1995) was used to compute unit concentration factors for the Hanford Site boundary for 24 hour and annual releases from the $100-\mathrm{N}$ (or $100-\mathrm{K}$ ), the 200 West, the 200 East, and 300 Areas. Hanford site wind data is used for these calculations. The data for each area was collected in that area. For the 24 hour releases, hourly data from 1992, 1993, 1994, and 1995 was used. For the annual releases the joint frequency summary for each area for the years 1986 to 1995 was used. Results are summarized in the first table below. These are the worst-case values for ground level releases from each area.

Table 1. Summary of Unit Concentration Factors for Ground Level Releases from Hanford Facilities

To use these factors, the rate at which a chemical is released into the air must be computed. To do this, the total amount (in grams) of the chemical released is divided by either 86,400 seconds ( 24 hours) or $31,557,600$ seconds (1 year). This release rate is then multiplied by one of the factors on Table 1 to compute the average concentration at the Hanford site boundary in $\mu \mathrm{g} / \mathrm{m}^{3}$. The formula below summarizes the calculation.

\begin{tabular}{|l|c|c|c|c|}
\hline \multirow{2}{*}{$\begin{array}{l}\text { Release } \\
\text { Locations }\end{array}$} & \multicolumn{2}{|c|}{24 Hour Average } & \multicolumn{2}{c|}{ Annual Average } \\
\cline { 2 - 6 } & $\begin{array}{c}\text { Concen. } \\
\text { Factor }\end{array}$ & $\begin{array}{c}\text { Site Boundary } \\
\text { Location }\end{array}$ & $\begin{array}{l}\text { Concen. } \\
\text { Factor }\end{array}$ & $\begin{array}{c}\text { Site Boundary } \\
\text { Location }\end{array}$ \\
\hline $100-\mathrm{N} \& \mathrm{KW}$ & 4.17 & $8.5 \mathrm{~km} \mathrm{WNW}$ & 0.125 & $8.5 \mathrm{~km}$ WNW \\
200 West Area & 3.46 & $12.6 \mathrm{~km}$ S & 0.0585 & $22.0 \mathrm{~km} \mathrm{SE}$ \\
200 East Area & 2.79 & $17.1 \mathrm{~km} \mathrm{ESE}$ & 0.0793 & $17.1 \mathrm{~km} \mathrm{ESE}$ \\
300 Area & 38.1 & $1.1 \mathrm{~km} \mathrm{E}$ & 1.56 & $1.3 \mathrm{~km} \mathrm{NE}$ \\
\hline
\end{tabular}

Note: Units for the Concentration Factors are $\mu \mathrm{g} / \mathrm{m}^{3} \mathrm{per} \mathrm{g} / \mathrm{s}$.

Note: Annual averages are based on Hanford Site wind data collected over the years 1986 to 1995 .

24 hour averages are based on hourly Hanford Site wind data for the years 1992, 1993, 1994, and 1995.

43 As an example, suppose that 10 grams of ammonia is released over a 24 hour 44 period from the 200 West Area. Then the largest observed air concentration at 45 the Hanford site boundary over the past four years is $0.0004 \mu \mathrm{g} / \mathrm{m}^{3}$ at a

46 location $12.6 \mathrm{~km}$ south of the 200 West Area. 


\section{Method of Calculating the Concentration Factors}

The first step was to estimate distances to the Hanford Site boundary from each of the areas of interest in all 16 wind transport directions. Table 2 shows the facilities selected and the distances obtained from the Hanford Map Distance (HMD) software by P.D. Rittmann.

Table 2. Distances (meters) to the Hanford Site Boundary

\begin{tabular}{|c|r|r|r|r|r|r|r|r|}
\hline \multirow{2}{*}{ Dir } & \multicolumn{2}{|c|}{$100-\mathrm{N}$ and $-\mathrm{K}$} & \multicolumn{2}{c|}{200 West } & \multicolumn{2}{c|}{200 East } & \multicolumn{2}{c|}{300 Area } \\
\cline { 2 - 9 } & $100 \mathrm{~N}$ & $100 \mathrm{KW}$ & CWC & REDOX & PUREX & WESF & 324 & 333 \\
\hline N & 9600 & 11000 & 17300 & 20300 & 24600 & 19400 & 7000 & 8700 \\
NNW & 8700 & 8900 & 15500 & 18100 & 21200 & 16700 & 46000 & 45500 \\
NW & 8300 & 8700 & 14600 & 17200 & 21300 & 18100 & 48600 & 48100 \\
WNW & 8500 & 10100 & 11800 & 13200 & 21200 & 19300 & 28500 & 28200 \\
W & 11500 & 12100 & 11500 & 13000 & 20700 & 18900 & 6000 & 6700 \\
WSW & 17300 & 15700 & 11800 & 13300 & 21100 & 19400 & 3500 & 4200 \\
SW & 20500 & 17400 & 13800 & 15500 & 17100 & 19900 & 2400 & 2900 \\
SSW & 28600 & 25600 & 15100 & 12800 & 16800 & 19600 & 2000 & 2700 \\
S & 28600 & 25200 & 14700 & 12600 & 19600 & 22800 & 1900 & 2400 \\
SSE & 34100 & 31000 & 19200 & 18200 & 19800 & 25500 & 1900 & 2400 \\
SE & 27300 & 32100 & 24700 & 22000 & 24300 & 19900 & 1500 & 1700 \\
ESE & 19100 & 21700 & 29900 & 28700 & 20200 & 17100 & 1200 & 1400 \\
E & 17300 & 20600 & 24300 & 25000 & 16000 & 16900 & 1100 & 1300 \\
ENE & 17300 & 20400 & 24600 & 23200 & 15300 & 21900 & 1100 & 1300 \\
NE & 16300 & 19900 & 27400 & 26400 & 18100 & 26400 & 1300 & 1500 \\
NNE & 13800 & 15200 & 25000 & 28800 & 23600 & 21100 & 1800 & 2200 \\
\hline
\end{tabular}

The second step was to obtain Hanford Site wind data from Kenneth $W$. Burk at PNNL. The wind data for each area is then used in the ISC3 calculations.

The third step is to create input files for the ISC3 software. Two of the input files are attached for reference. The first is an annual average calculation using ISCLT, while the second is a 24 hour calculation using ISCST. Both use a release height of 2 meters, with an exhaust flow rate of 2000 cubic feet per minute $(56,634$ liters per minute) at a temperature of $20^{\circ} \mathrm{C}$. These conditions model ground level releases.

The final step was to arrange the ISC 3 results into Tables 3 and 4 . The worst case concentration factor was taken for each area. These worst-case results are 1 isted in Table 1. 


\begin{tabular}{|c|c|c|c|c|c|c|c|c|}
\hline \multicolumn{3}{|c|}{ Table 3. Annual } & \multicolumn{6}{|c|}{ Average Concentration Factors $\left(\mu \mathrm{g} / \mathrm{m}^{3}\right.$ per $\left.\mathrm{g} / \mathrm{s}\right)$} \\
\hline \multirow{2}{*}{ Dir } & \multicolumn{2}{|c|}{$100-N$ and $-K$} & \multicolumn{2}{|c|}{200 West } & \multicolumn{2}{|c|}{200 East } & \multicolumn{2}{|c|}{300 Area } \\
\hline & $100 \mathrm{~N}$ & $100 \mathrm{KW}$ & CWC & REDOX & PUREX & WESF & 324 & 333 \\
\hline \multirow[t]{2}{*}{$\begin{array}{c}N \\
N N W \\
N W \\
W N W \\
W \\
W S W \\
S W \\
\text { SSW } \\
S \\
\text { SSE } \\
\text { SE } \\
\text { ESE } \\
\text { E } \\
\text { ENE } \\
\text { NE } \\
\text { NNE }\end{array}$} & $\begin{array}{l}0.0500 \\
0.0656 \\
0.1064 \\
0.1252 \\
0.0863 \\
0.0373 \\
0.0234 \\
0.0126 \\
0.0136 \\
0.0131 \\
0.0230 \\
0.0504 \\
0.0661 \\
0.0555 \\
0.0389 \\
0.0318 \\
\end{array}$ & $\begin{array}{l}0.0410 \\
0.0635 \\
0.0993 \\
0.0973 \\
0.0803 \\
0.0427 \\
0.0293 \\
0.0146 \\
0.0161 \\
0.0148 \\
0.0186 \\
0.0423 \\
0.0520 \\
0.0442 \\
0.0295 \\
0.0277 \\
\end{array}$ & $\begin{array}{l}0.0249 \\
0.0311 \\
0.0381 \\
0.0351 \\
0.0290 \\
0.0233 \\
0.0212 \\
0.0246 \\
0.0366 \\
0.0368 \\
0.0500 \\
0.0532 \\
0.0505 \\
0.0306 \\
0.0182 \\
0.0153 \\
\end{array}$ & $\begin{array}{l}0.0200 \\
0.0251 \\
0.0303 \\
0.0299 \\
0.0243 \\
0.0196 \\
0.0179 \\
0.0312 \\
0.0457 \\
0.0396 \\
0.0585 \\
0.0562 \\
0.0486 \\
0.0331 \\
0.0191 \\
0.0127 \\
\end{array}$ & $\begin{array}{l}0.0136 \\
0.0216 \\
0.0220 \\
0.0173 \\
0.0150 \\
0.0112 \\
0.0154 \\
0.0153 \\
0.0147 \\
0.0189 \\
0.0289 \\
0.0629 \\
0.0585 \\
0.0366 \\
0.0207 \\
0.0117 \\
\end{array}$ & $\begin{array}{l}0.0187 \\
0.0300 \\
0.0276 \\
0.0197 \\
0.0171 \\
0.0126 \\
0.0124 \\
0.0123 \\
0.0119 \\
0.0133 \\
0.0380 \\
0.0793 \\
0.0542 \\
0.0224 \\
0.0124 \\
0.0136 \\
\end{array}$ & $\begin{array}{l}0.145 \\
0.011 \\
0.014 \\
0.017 \\
0.059 \\
0.079 \\
0.157 \\
0.403 \\
0.992 \\
1.171 \\
1.248 \\
1.142 \\
1.184 \\
1.382 \\
1.558 \\
0.975 \\
\end{array}$ & $\begin{array}{l}0.106 \\
0.012 \\
0.014 \\
0.017 \\
0.050 \\
0.060 \\
0.117 \\
0.255 \\
0.696 \\
0.823 \\
1.036 \\
0.917 \\
0.933 \\
1.082 \\
1.256 \\
0.719 \\
\end{array}$ \\
\hline & D. & 24 Hour & \multicolumn{2}{|c|}{$\begin{array}{l}\text { Average Concentrati } \\
\text { from Ground Level }\end{array}$} & $\begin{array}{l}\text { ion Facto } \\
\text { Releases }\end{array}$ & & er $\mathrm{g} / \mathrm{s}$ & \\
\hline \multirow{2}{*}{ Dir } & \multicolumn{2}{|c|}{$100-\mathrm{N}$ and $-\mathrm{K}$} & \multicolumn{2}{|c|}{200 West } & \multicolumn{2}{|c|}{200 East } & \multicolumn{2}{|c|}{300 Area } \\
\hline & $100 \mathrm{~N}$ & $100 \mathrm{KW}$ & $\mathrm{CWC}$ & REDOX & PUREX & WESF & 324 & 333 \\
\hline $\begin{array}{c}N \\
N N W \\
N W \\
W N W \\
W \\
W S W \\
S W \\
S S W \\
S \\
S S E \\
S E \\
\text { ESE } \\
\text { E } \\
\text { ENE } \\
N E \\
\text { NNE }\end{array}$ & $\begin{array}{l}3.75 \\
3.20 \\
2.29 \\
4.17 \\
2.51 \\
1.42 \\
0.81 \\
0.92 \\
0.90 \\
0.81 \\
0.51 \\
1.62 \\
3.23 \\
2.71 \\
0.61 \\
2.36\end{array}$ & $\begin{array}{l}3.30 \\
3.13 \\
2.17 \\
3.51 \\
2.35 \\
1.57 \\
0.96 \\
1.02 \\
1.01 \\
0.90 \\
0.41 \\
1.44 \\
2.76 \\
2.30 \\
0.48 \\
2.15\end{array}$ & $\begin{array}{l}1.96 \\
3.30 \\
0.78 \\
2.16 \\
3.24 \\
1.90 \\
0.79 \\
1.92 \\
3.02 \\
2.64 \\
0.99 \\
2.51 \\
2.44 \\
1.69 \\
0.91 \\
1.96\end{array}$ & $\begin{array}{l}1.70 \\
2.84 \\
0.64 \\
1.94 \\
2.91 \\
1.69 \\
0.71 \\
2.30 \\
3.46 \\
2.78 \\
1.12 \\
2.61 \\
2.38 \\
1.78 \\
0.95 \\
1.70\end{array}$ & $\begin{array}{l}1.29 \\
1.95 \\
0.53 \\
1.16 \\
1.74 \\
0.29 \\
1.31 \\
1.39 \\
1.69 \\
1.31 \\
1.00 \\
2.36 \\
1.73 \\
1.10 \\
0.41 \\
0.97\end{array}$ & $\begin{array}{l}1.71 \\
2.45 \\
0.62 \\
1.28 \\
1.89 \\
0.32 \\
1.13 \\
1.20 \\
1.48 \\
1.02 \\
1.29 \\
2.79 \\
1.64 \\
0.73 \\
0.26 \\
1.08\end{array}$ & $\begin{array}{l}5.91 \\
0.52 \\
0.29 \\
1.12 \\
4.25 \\
6.05 \\
4.79 \\
1.91 \\
7.25 \\
0.01 \\
6.44 \\
8.42 \\
8.11 \\
7.63 \\
1.38 \\
6.36\end{array}$ & $\begin{array}{l}4.47 \\
0.53 \\
0.30 \\
1.13 \\
3.66 \\
5.08 \\
3.97 \\
8.91 \\
9.85 \\
5.84 \\
3.08 \\
4.65 \\
0.78 \\
2.98 \\
8.12 \\
3.08\end{array}$ \\
\hline
\end{tabular}

42 


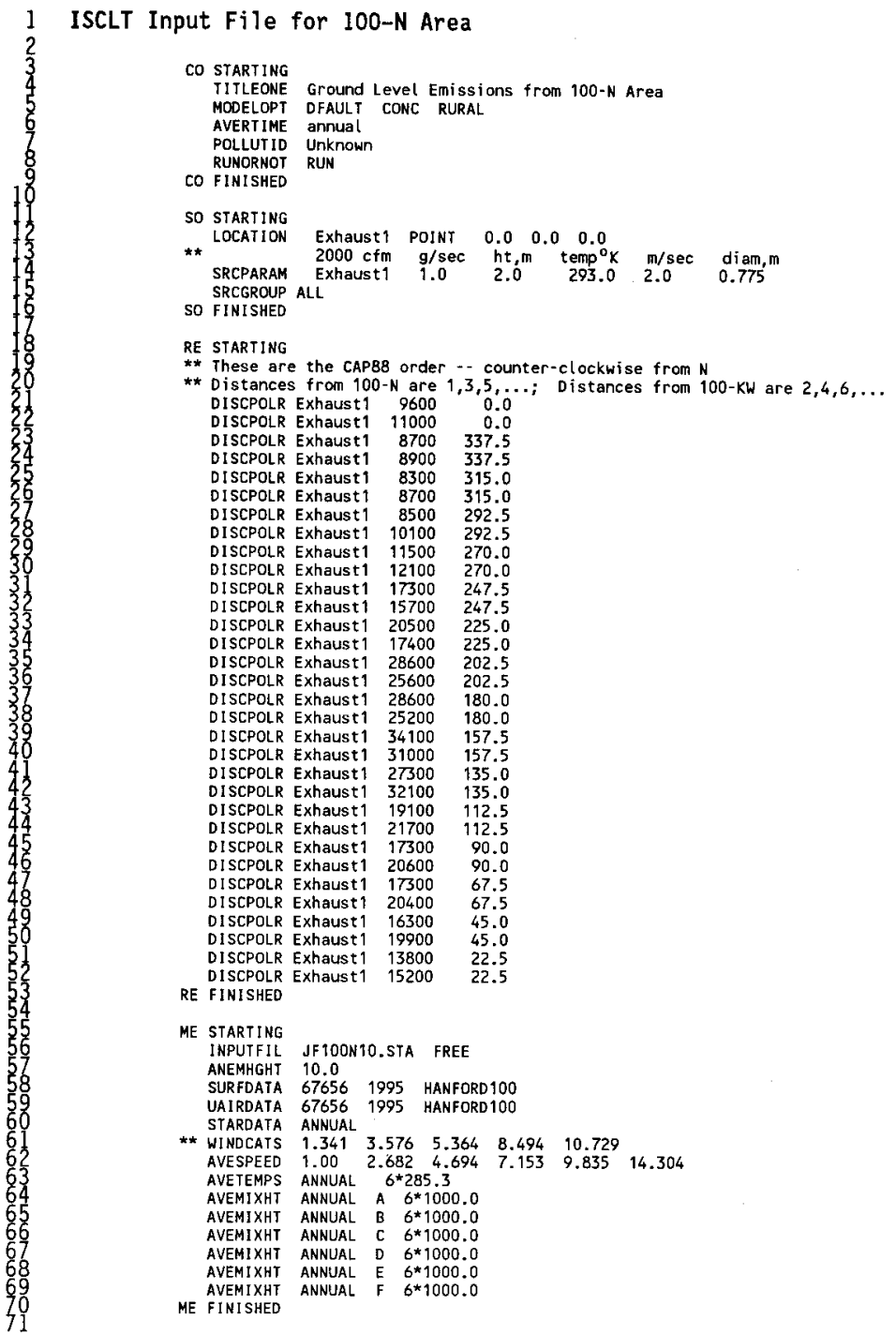


OU STARTING

RECTABLE SRCGRP

MAXTABLE 10 INDSRC SOCONT

OU FINISHED

\section{ISCST Input File for 200 West Area}

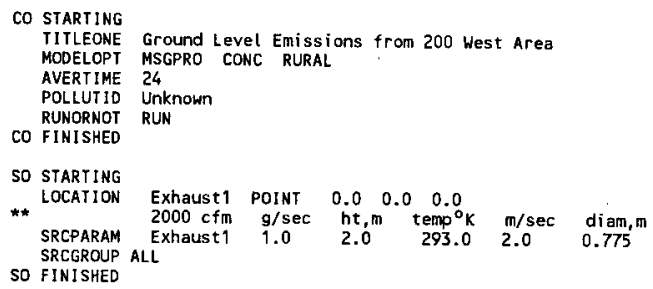


D0E/RL-97-15, Rev. 0

$02 / 97$

\author{
APPENDIX B \\ CALCULATION OF POLLUTANT INVENTORY IN TANK SLUDGE
}


DOE/RL-97-15, Rev. 0

02/97

1
2
3
4
5

This page intentionally left blank. 
The inventory of pollutant in tank sludge (Inv) is calculated as follows:

$\operatorname{Inv}=(C)(S V)$

$c=$ Concentration of pollutant in tank sludge (refer to "Sample Data" below).

$S V=$ Volume of sludge in waste tanks. The combined volume of sludge in the six tanks is 1,670 liters, based on calculation using an average sludge depth of 3.81 centimeters and a tank radius of 152.4 centimeters.

(II) (tank radius) ${ }^{2}$ (avg. sludge depth per tank) (number of tanks)

Sample Data: $340 \mathrm{~A}$ Building tank solids have not been sampled/analyzed for nonradiological pollutants. However, because the $340 \mathrm{~A}$ Building tanks provide reserve storage capacity for liquid effluents normally discharged to the 340 Vault tanks, nonradiological pollutant sample/analysis data from the 340 Vault tanks (average concentrations from 1991 to 1995) was used to estimate pollutant concentrations in the $340 \mathrm{~A}$ Building tanks. To account for possible increased pollutant concentrations in the $340 \mathrm{~A}$ Building tanks (relative to concentrations in the 340 Vault tanks), pollutant concentrations were assumed to be 10 times greater those in the 340 vault tanks. The following are the estimated concentrations of TAPs and Criteria Pollutants in the $340 \mathrm{~A}$ Building tanks.

- Barium (10.26 milligrams per liter)

- Cadmium (40.8 E-1 milligrams per liter)

- Chromium (90.34 milligrams per liter)

- Lead (50.42 milligrams per liter)

- Silver (90.5 E-1 milligrams per liter)

- Mercury (50.69 E-2 milligrams per 7iter)

- Arsenic (50.92 E-2 milligrams per 1iter)

- Selenium (10.07 milligrams per liter). 
D0E/RL-97-15, Rev. 0

$02 / 97$

This page intentionally left blank. 
DOE/RL-97-15, Rev. 0

$02 / 97$

1
2
3
4
5

\author{
APPENDIX C \\ CALCULATION OF POLLUTANT INVENTORY RESUSPENDED \\ INTO TANK VAPOR SPACE
}


DOE/RL-97-15, Rev. 0

$02 / 97$

This page intentionally left blank.

970210.1053

APP $\mathrm{C}-\mathrm{i} i$ 
The inventory of pollutant resuspended into tank vapor space (InvR) is 2 calculated as follows:

3

$4 \quad$ InvR $=($ Inv $)(R F)$

5 Inv $=$ Inventory of pollutant in tank sludge

7 (refer to text, Table 1).

$9 \mathrm{RF}=\quad$ The release fraction for each pollutant is assumed to be

100.001 (based on information provided in 40 CFR 61,

11 Appendix D). 
DOE/RL-97-15, Rev. 0

$02 / 97$

1

2

3

4

5

This page intentionally left blank. 


\author{
APPENDIX D \\ ESTIMATED AVERAGE TOXIC AIR POLLUTANTS CONCENTRATION AT \\ THE POINT-OF-RELEASE TO THE ENVIRONMENT \\ DURING TANK SOLIDS REMOVAL ACTIVITIES
}


D0E/RL-97-15, Rev. 0 $02 / 97$

This page intentionally left blank. 
1 The estimated average concentrations of TAPS at the point-of-release to the 2 environment during air tank solids removal activities (EATC) are calculated as 3 follows:

4

$5 \quad E A T C=($ InVR $)(1 / V)(D F)$

6

InvR $=$ Inventory of TAPs resuspended into tank vapor space (refer to text, Table 1).

$V=\quad$ Volume of gas discharged from the 340 Facility K1 powered exhaust/ventilation system during the tank solids removal activities. This value is expected to be approximately 36,144 cubic meters. This value was determined by multiplying the estimated length of time that tank solids removal operations are expected to occur (12 hours, based on the assumption that each tank will require approximately 2 hours of solids removal activities) by the exhaust/ventilation system flow rate (50.2 cubic meters per minute).

Filtration system decontamination factor. The overal1 particulate decontamination factor (DF) for the control system was determined by multiplying the individual component DFs together. A DF of .0005 [based on 99.95 percent removal efficiency (Section 3.2.3)] was used for each high-efficiency particulate filter. The overall $D F$ is $2.5 \mathrm{E}-7$. 


\section{DOE/RL-97-15, Rev. 0}

This page intentionally left blank. 
DOE/RL-97-15, Rev. 0

$02 / 97$

1
2
3
4

APPENDIX E

ESTIMATED EMISSIONS RATE OF CRITERIA POLLUTANTS 
DOE/RL-97-15, Rev. 0

$02 / 97$

1

2

3

4

5

This page intentionally left blank. 
1 The estimated emission rates of Criteria Pollutants (EERCP) are calculated as 2 follows:

3

4 EERCP $=($ ICPRTVS $)(D F)$

5

6 ICPRTVS = Inventory of Criteria Pollutants resuspended into tank

$7 \quad$ vapor space (refer to text, Table 2).

Filtration system decontamination factor. The overall particulate decontamination factor (DF) for the control system was determined by multiplying the individual component DFs together. A DF of .0005 [based on 99.95 percent removal efficiency (Section 3.2.3)] was used for each high-efficiency particulate filter. The overall $\mathrm{DF}$ is $2.5 \mathrm{E}-7$. 
DOE/RL-97-15, Rev. 0

02/97

This page intentionally left blank. 


\section{DISTRIBUTION}

S. M. Alexander

Perimeter Section

Washington State Department of Ecology

1315 West Fourth Avenue

Kennewick, Washington 99336-6018

S. E. Mckinney

Hanford Project Manager

Washington State Department of Ecology

P. 0. Box 47600

07ympia, Washington 98504-7600

M. Szyszkowski

Nuclear Waste Program

Washington State Department of Ecology

P. 0. Box 47600

0lympia, Washington 98504-7600

J. Wilkinson

Confederated Tribes of the Umatilla

Indian Nation

P. 0. Box 638

Pendleton, Oregon 97801

D. Powaukee

Nez Perce Tribe

P. 0. Box 365

Lapwai, Idaho 93540

R. Jim, Manager

Environmental Restoration/

Waste Management Program

Yakama Indian Nation

P. 0. Box 151

Toppenish, Washington 98948

ONSITE

U.S. Department of Energy, Richland Operations office

A. V. Beard

S7-55

G. M. Bell

A4-52

J. E. Rasmussen

A5- 15

H. M. Rodriguez

A5-15

A. B. Sidpara

S7-54

D. J. Williams

$\mathrm{H} 2-53$

Reading Room (2)

H2 -53 


\section{DISTRIBUTION (cont)}

MSIN

Fluor Daniel Hanford, Inc.

J. A. Bates

H6-36

B. D. Williamson

B3-15

Lockheed Martin Services, Inc.

Central Files

A3-88

DPC

EDMC (2)

H6- 08

H6-08

Pacific Northwest National Laboratory

Hanford Technical Library

$\mathrm{Kl}-11$

Rust Federal Services of Hanford Inc.

L. D. Berneski

L6-40

B. L. Curn

H6-36

W. E. Davis

L. P. Diediker

H6-36

B. P. Gleckler

H6-36

E. M. Greager

H6-36

W. E. Green

H6-36

D. L. Halgren

H6-36

L6-04

J. S. Hill

H6-25

M. T. Jansky

H6-21

J. J. Luke

H6-25

L. W. Roberts

L6-04

R. W. Szelmeczka

L6-05

G. T. Wells

H6-36

Air Operating Permit File

H6-25 